UDC 656.2

DOI: https://doi.org/10.32782/2520-2200/2020-4-23

Chornopyska Nataliya, Stasiuk Kateryna

Lviv Polytechnic National University

Чорнописька Н.B.

кандидат економічних наук, доцент кафедри маркетингу і логістики

Національного університету «Львівська політехніка»

Стасюк К.3.

аспірант

Національного університету «Львівська політехніка»

\title{
RAILWAY MARKET LIBERALIZATION PROGRESS: THE UKRAINIAN CASE
}

\section{ПОСТУП ЛІБЕРАЛІЗАЦІЇ РИНКУ ЗАЛІЗНИЧНИХ ПЕРЕВЕЗЕНЬ: УКРАÏНСЬКИЙ КЕЙС}

Ukrainian rail freight market stakeholders are identified. An empirical study results for key stakeholders participating in the Ukrainian railway reforming process are presented. The current market state opinions of stakeholder representatives, as well as their expectations considering future rail freight market changes due to liberalization are summarized. The current liberalization progress is represented by current (rather acute) problems expressed by respondents. The interest level and individual stakeholders influence importance has been determined, providing a basis for building a rail freight market stakeholders map. Strategic stakeholder groups have been identified and interaction strategies for each have been proposed. Specific stakeholder interaction methods have been presented contributing into these strategies implementation and the global goal achievement - the railway industry of Ukraine development.

Keywords: liberalization, railway market, freight transportation, stakeholder marketing, marketing research, stakeholders, interaction strategies.

Залізниця сприяє розвитку економіки, забезпечує стійку мобільність, захист довкілля та міжнародну інтеграцію і тому потребує посиленої уваги в сучасній ситуації. Лібералізація ринку залізничних перевезень покликана вирішити ряд критично важливих та невирішених проблем галузі, підвищити конкурентоспроможність української залізниці, інтегрувати іï у єдиний транспортний простір ЄС. В Україні запущено процес лібералізації, проте на першому ж законодавчому етапі і призупинено. Це актуалізує проблему виявлення зацікавлених сторін (стейкхолдерів) у реформуванні ринку залізничних перевезень та дослідження ринку з їхнього погляду. Метою статті $€$ представлення результатів емпіричних досліджень “що думають ключові стейкхолдери про український ринок залізничних вантажних перевезень", а також обгрунтування доцільності використання інструментів маркетингу відносин на шляху лібералізації ринку залізничних перевезень. У процесі дослідження використано такі методи: аналіз, узагальнення, порівняння, формалізація, опитування, побудова матриць. В результаті дослідження ідентифіковано стейкхолдерів ринку залізничних вантажних перевезень України. Представлено результати емпіричного дослідження ключових зацікавлених сторін у реформуванні української залізниці. Узагальнено думки респондентів (представників стейхолдерів) щодо поточного стану ринку, а також їхні очікування(прогнози) щодо зміни майбутнього ринку залізничних вантажних перевезень внаслідок лібералізації. Поточний поступ лібералізації представлено актуальними проблемами, які висловили учасники опитування. Визначено ступінь зацікавленості та вагомість впливу окремих стейкхолдерів, на підставі чого побудовано карту стейкхолдерів ринку залізничних вантажних перевезень. Виділено стратегічні групи стейхолдерів та запропоновано стратегії взаємодії для кожної. Подано конкретні методи взаємодії стейкхолдерів, що сприятиме втіленню зазначених стратегій та досягненню глобальної цілі - розвитку залізничної галузі України.

Ключові слова: лібералізація, ринок залізничних перевезень, вантажні перевезення, маркетинг відносин, маркетингове дослідження, стейкхолдери, стратегії взаємодії. 
Идентифицировано стейкхолдеров рынка железнодорожных грузовых перевозок Украины. Представлены результаты эмпирического исследования ключевых заинтересованных сторон в реформировании украинской железной дороги. Обобщены мнения респондентов (представителей стейкхолдеров) о текущем состоянии рынка, а также их ожидания (прогнозы) по изменению будущего рынка железнодорожных грузовых перевозок в результате либерализации. Текущий прогресс либерализации представлено актуальными проблемами, которые выразили участники опроса. Определена степень заинтересованности и весомость влияния отдельных стейкхолдеров, на основании чего построено карту стейкхолдеров рынка железнодорожных грузовых перевозок. Выделены стратегические группы стейкхолдеров и предложены стратегии взаимодействия для каждой. Представлены конкретные методы взаимодействия стейкхолдеров, что будет способствовать воплощению указанных стратегий и достижению глобальной цели - развития железнодорожной отрасли Украины.

Ключевые слова: либерализация, рынок железнодорожных перевозок, грузовые перевозки, маркетинг отношений, маркетинговое исследование, стейкхолдеры, стратегии взаимодействия.

Formulation of the problem. Railway transport is the basis of Ukraine's transport system, but it is currently in a state of uncertainty. The rail freight industry has a number of unresolved issues. All types of connections traffic reduction is registered: export - by $7.5 \%$; internal communication - by $3.1 \%$; transit - by $16.4 \%$; import - by $0.6 \%$ [1]. There has been a high level of depreciation for fixed assets: the cars inventory decreased by more than 2 times in the period from 1992 to $2018 ; 40 \%$ of tracks need major repairs and modernization. There has been lack of locomotives: it is critical to buy about 500 locomotives. Without radical changes, the loss of rail transport market share will continue to grow. The unstable financial condition of JSC "Ukrainian Railways" deserves a separate statement. There is a significant debt burden: interest loans and borrowings of JSC "Ukrainian Railways" as of 2018 amount to more than 30,000 million UAH; insufficient investment attraction due to legal restrictions, high political and economic risks - in 2018, $68.4 \%$ of the rolling stock renewal program measures were implemented at the expense of investment funds [2]. Social obligations are performed in the absence of state support: unprofitable passenger traffic is subsidized by freight transportations. Because of the outdated and inefficient organizational structure, the management staff needs to be reduced and optimized the operational staff motivation increasing measures are to be taken. Imperfect public procurement system means that the implemented tender procurement systems do not fulfill their main function - economy and transparency. High staff turnover is due to unsatisfactory wages. Many of the above stated, as well as other problems can be solved at the level of legislation and market regulation. The railway market liberalization process has proved its effectiveness at the global level; this is the exact necessary scenario for overcoming the whole industry and its individual enterprises crisis. Ukraine has started the liberalization process, but it has been suspended at the first legislative stage (a new bill adoption process "On Railway Transport of Ukraine", which considers market liberalization, is long and still unsuccessful). Thus, the problem of stakeholders research and identification in the railway market reform becomes increasingly actual, requiring clarification of such questions as: what is the interest of each party (political/economic/public interest)? What motivates stakeholders (money/ result)? What is the best way for interaction? What result do they want (success/defeat)? It is also necessary to perform market research from their point of view, which will best reflect the current situation and the progress level for liberalization.

Recent researches and publications analysis. We consider the scientific work on the theory of stakeholders of Freeman, Harrison, Wicks, Parmar and DeColle [3] as fundamental. A group of researchers has suggested that business has stakeholders - groups and individuals who have a share in the success or failure of this business. The issue of interaction aspects with stakeholders has an important place in the various level researches of world organizations including The World Business Council for Sustainable Development, Stakeholder Research Associates, Business for Social Responsibility, The Future 500, Global Leadership Network. A special attention should be payed to The Stakeholder Marketing Consortium, which is a forum for innovation and research through the world's leading marketers and practitioners collaboration Bhattacharya, Korschun [4]. The impact of marketing activities on various stakeholders study was considered the main issue of the event.

In Ukraine, specialized institutes are engaged in complex research for the railway transportation market, including the Ukrainian Institute for the Future, the Center for Transport Strategy, Infrastructure Council, Ukrainian Transport Union, Center for Economic Strategy. The railway industry has its own individual and unique features that need to be considered when working with stakeholders. There remains at enough specially 
adapted recommendations and interaction strategies for stakeholders, so the issue is relevant for research. The study [5] authors studied one of the important stakeholders in the rail transportation area - customers and substantiated the importance of rail freight liberalization for improving the customer service quality. There is a separate unit in the Integrated Report of JSC "Ukrainian Railways" for 2018 [6] highlighting the issue of interaction with stakeholders, but special attention is paid only to interaction with public and international organizations. The issue of comprehensive research for all stakeholders in the railway market reform needs further development.

The purpose of the article include a presentation of the empirical research results on "what key stakeholders think about the Ukrainian rail freight market", as well as a rationale for stakeholder marketing tools usage to liberalize the rail market.

Outline of the main research material. The authors' empirical research was preceded by a stage of collecting, grouping and generalizing information on the main players and stakeholder groups in reforming the railway market of Ukraine. A list of railway market stakeholders was formed based on the results of railway transportations area researches $[6 ; 7 ; 8 ; 9]$ analysis and authors' previous study [10]:

1. JSC "Ukrainian Railways" plays a leading role, still maintaining a monopoly. The Cabinet of Ministers of Ukraine owns JSC “Ukrainian Railways", which explains the intertwining of both economic and political interests. It is a stakeholder that deserves special attention in terms of interests area and influence weight.

2. Carriers (competitors) compose a group of enterprises (Association of Ukrainian Railway Carriers) having the ability to perform rail transportation of their products independently. Also includes intersectoral competition (cars, air and sea carriers).

3. The industry employees form a large group and follow primarily their personal interests (material remuneration for work, stability, social security).

4. Business partners (suppliers, contractors) consist of large number of suppliers, which can be grouped into: rolling stock/spare parts/equipment manufacturers, fuel suppliers, maintenance and repair contractors.

5. Cargo owners (customer) are various industry clients: coal, chemical, forestry, furniture, brewing, printing, electronic, food, metallurgy, engineering.

6. Ukrainian government consists of state bodies (Cabinet of Ministers of Ukraine, Ministry of Infrastructure of Ukraine etc.) and local authorities (the railway network is widely branched, so local communities interact with the railway), adheres to the law and takes an active part in addressing socially sensitive issues.

7. International organizations and communities: Ukraine's European integration process envisages the railway interaction with international organizations including the European Bank for Reconstruction and Development, the World Bank, the Trans-Caspian International Transport Route, and also interaction with the neighboring country railways.

8. Financial and credit institutions provide an important interaction with stakeholders, which will allow the latter to attract financial resources. It is possible to achieve the loan portfolio improvement by working in this area effectively. Cooperation with financial and credit institutions contributes to the implementation of strategic objectives, reducing fixed assets depreciation share, improving infrastructure and other. There is a chance for development of the Ukrainian railway industry and its individual enterprises by attracting and properly implementing investments.

9. Non-governmental organizations cooperate with Ukrainian and foreign public organizations that develop initiatives aimed at supporting and ensuring sustainable development, encouraging volunteering that contributes to global goals achievement in sustainable development.

10. Mass media are constantly focused on the railway market as one of the basic Ukraine's economies.

The authors' empirical research was aimed at the most active stakeholders group - carriers joining into the Association of Ukrainian Railway Carriers, which aimed to intensify investment in the industry by joint efforts and assist railway enterprises with functioning and development. Currently, this group of stakeholders is represented by 10 companies [11]. Google Form questionnaire developed by the authors for a comprehensive railway freight industry study was selected as a research tool. A separate block of the questionnaire included questions about the market and was selected for further consideration fulfilling the article aims. Research methodology - survey:

- by the surveyed population coverage degree-overall;

- by the communication method between the respondent and the researcher - online mode (as the period coincided with the country's quarantine restrictions period) using: e-mail (30\%), Facebook (50\%), Linkedln (20\%);

- by formalization degree - formalized;

- by meaning - surveys considering facts, events;

- by respondent type - surveys for top managers;

- the study period: April-May 2020.

The research results are presented in the form of infographics on Figure 1. 


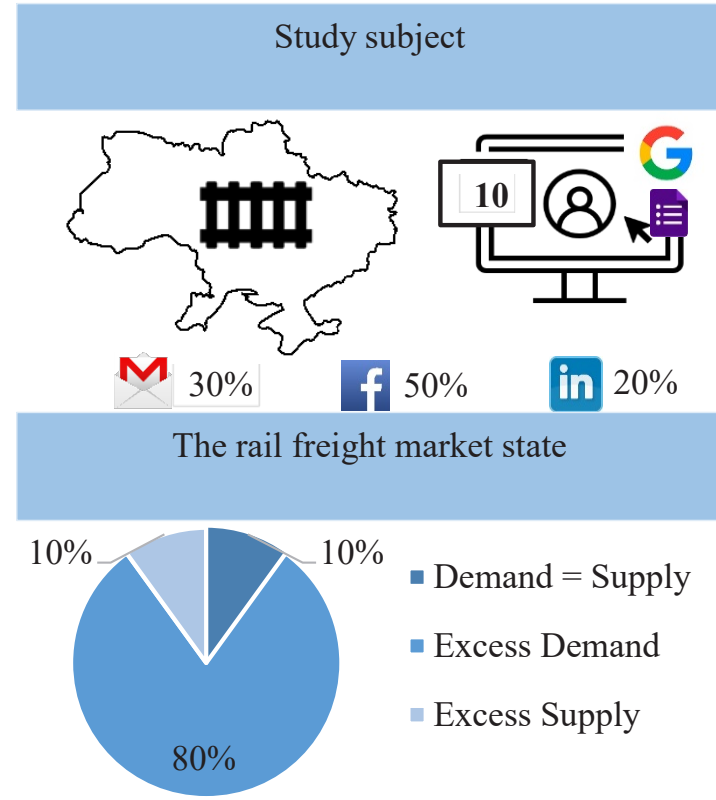

Do you expect competitors to appear on the market?

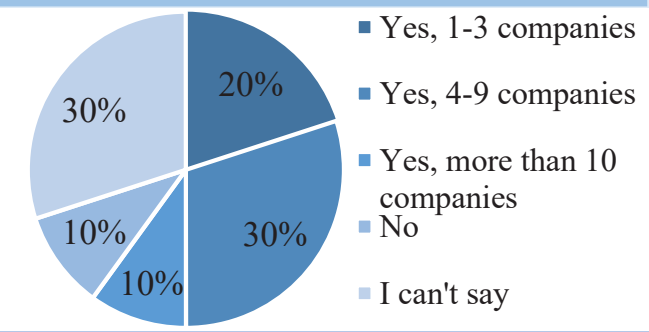

The railway market liberalization attitude

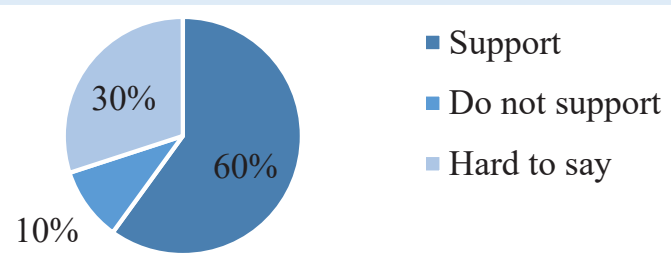

Demand behavior for the next three years?

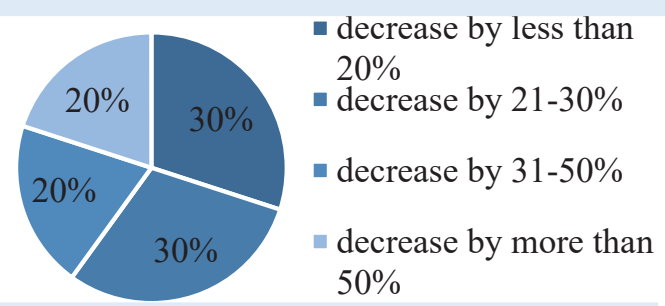

How will the average level of tariffs change with the competitors' arrival?

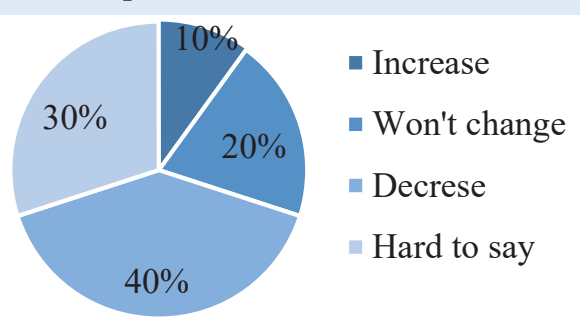

Railway market stakeholders map

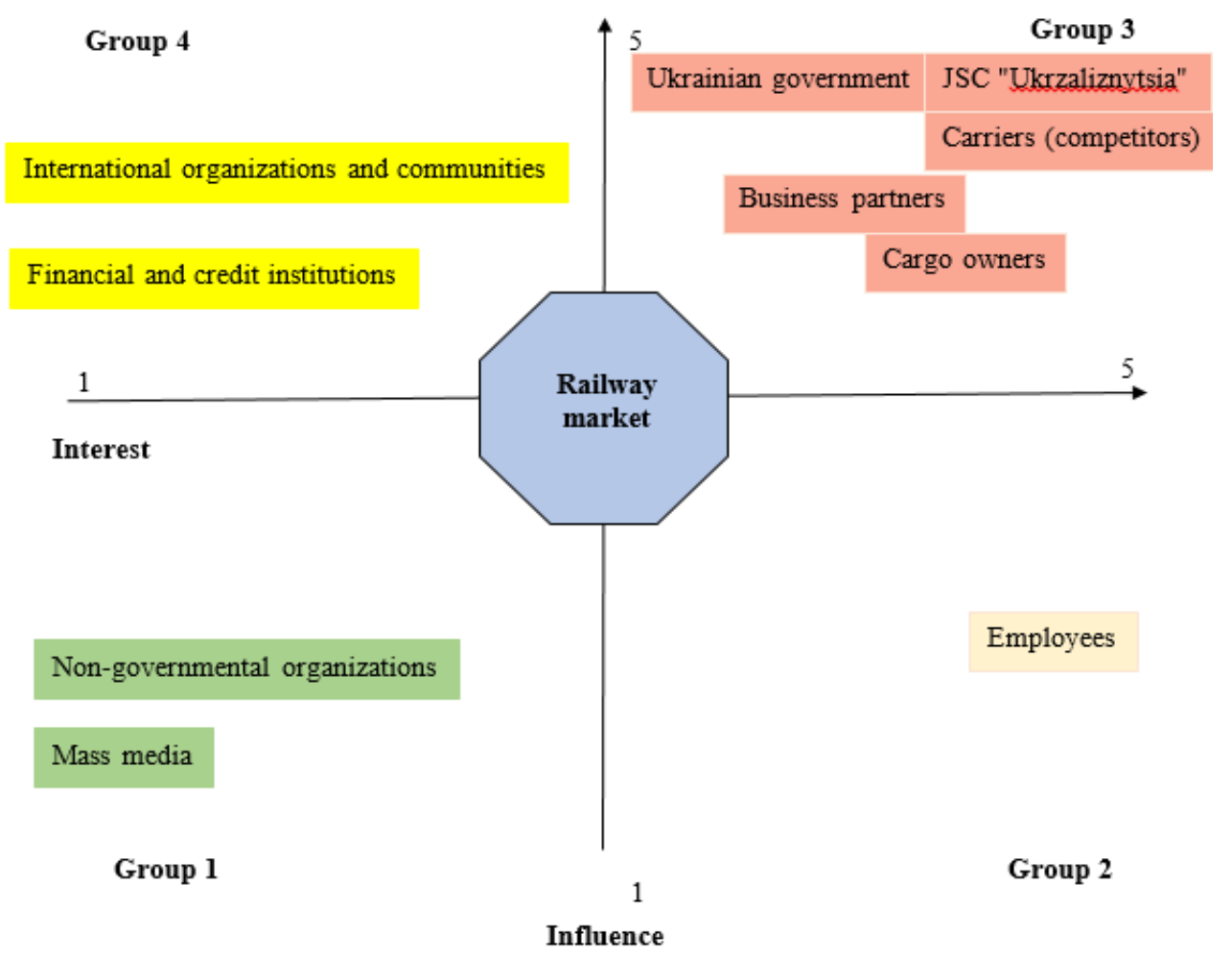

Figure 1. Infographics for the railway freight market research

Source: authors' own elaboration based on primary research 


\begin{tabular}{|c|c|}
\hline $\begin{array}{c}\text { Group 4 - Keep Satisfied } \\
\text { «low interest \& high influence» }\end{array}$ & $\begin{array}{c}\text { Group 3 - Win-Win } \\
\text { «high interest \& high influence» }\end{array}$ \\
\hline $\begin{array}{c}\text { Group 1 - Keep Support } \\
\text { «low interest \& low influence» }\end{array}$ & $\begin{array}{c}\text { Group 2 - Keep Informed } \\
\text { «high interest \& low influence» }\end{array}$ \\
\hline
\end{tabular}

Figure 2. Stakeholder strategic groups and interaction strategies

Source: elaborated by authors on the basis of [12]

Special attention should be payed to obtained stakeholders map illustrating the obtained data adequacy and demonstrating study's practical value. Stakeholders positioning within the matrix "degree of interest - weight of influence" enables strategic stakeholder groups' identification and building appropriate interaction strategies: (Figure 2).

Group 1 "low interest \& low influence". This stakeholders group includes public organizations and mass media according to the respondents. They have some influence on public opinion and the industry image formation. Recommended interaction strategy - Keep Support.

Group 2 "high interest \& low influence". This group requires special attention, because employees are the internal engine for any industry. Recommended strategy - Keep Informed.

Group 3 "high interest \& high influence". The group includes key players / stakeholders, interaction with which will greatly affect the future of Ukrainian railway transport. Recommended interaction strategy - Win-Win. Effectively organized interaction can also provide global results: pooling resources (financial, labor, technological), improving business processes and increasing operational efficiency, effective risk management, new strategic opportunities identifying, the competitiveness advance for each enterprise apart and the industry as a whole.

Group 4 "low interest \& high influence". Stakeholders forming this group include international organizations and communities, financial and credit institutions according to the research results. It is the industry that is more interested in this stakeholders group (than vice versa), because they accumulate knowledge, experience, finances, which are so necessary for development. Recommended interaction strategy Keep Satisfied.

Table 1 generalizes stakeholders interaction methods.

Appropriate stakeholder interaction methods will contribute to appropriate strategies implementation, which will advance the global goal achievement: development of the railway industry of Ukraine.
Summary of the research. The research proved that the rail freight market supply is not able to meet existing demand. $80 \%$ of respondents described the current situation as "demand exceeds supply". The major problems mentioned by the respondents include:

- Technical-technological: lack of modern equipment, impossibility for it to be purchased; locomotives and cars insufficient number; seasonality - cargo owners of other industries experience problems during the agricultural season;

- Competence: lack of qualified personnel at stations, in all the services; unsatisfactory salaries for employees;

- Quality: unforeseen transportation terms; late deliveries;

- Security: dangerous situation risks; thefts;

- Legal: non-alternative and state monopoly on railway transportation; imperfect transport legislation; low level of legal responsibility; business corruption;

- System: bureaucracy; low level of flexibility and modernization resistance.

This situation provokes a drop in demand being expected by all carriers in the near future $130 \%$ of respondents predict a decrease by less than $20 \%$; $30 \%$ of respondents - decrease by $21-30 \% ; 20 \%$ of respondents - decrease by $31-50 \%$ and $20 \%$ predict a decrease by more than $50 \%$ ). This means the loss of freight transportation market share for railways in favor mainly to road transport.

Deep structural reforms implementation urgency is obvious. $60 \%$ of respondents support the liberalization process, only $10 \%$ do not support and it is difficult to determine their attitude to liberalization for $30 \%$. Liberalization means a competitive rail market. However, according to respondents, there will not be many of them: $30 \%$ of respondents prognose $4-9$ new competitors appearance in its segment; $10 \%$ of respondents - more than $10 ; 20 \%$ of respondents expect the arrival of a maximum of 3 new competitors in its segment, as there are very high entry barriers. Competition will advance the issue of tariff formation (the current tariff guide is inherited from Soviet times). The respondent opinions split: $40 \%$ of respondents believe the tariff will decrease; 
Table 1

Stakeholder interaction methods and strategies

\begin{tabular}{|c|c|c|c|}
\hline Group & Stakeholders & Interaction methods & Strategies \\
\hline \multirow{2}{*}{$\begin{array}{l}\text { Group } 4 \text { "low interest } \\
\text { \& high influence" }\end{array}$} & $\begin{array}{l}\text { International } \\
\text { organizations and } \\
\text { communities }\end{array}$ & $\begin{array}{l}\text { Surveying; Joint projects } \\
\text { development promotion; } \\
\text { International community opinions } \\
\text { consideration; Talks. }\end{array}$ & \multirow{2}{*}{ Keep Satisfied } \\
\hline & $\begin{array}{l}\text { Financial and credit } \\
\text { institutions }\end{array}$ & $\begin{array}{l}\text { Currently organized special } \\
\text { projects; Financial ratings; } \\
\text { Information transparency and } \\
\text { openness. }\end{array}$ & \\
\hline \multirow{5}{*}{$\begin{array}{l}\text { Group } 3 \text { "high } \\
\text { interest \& high } \\
\text { influence" }\end{array}$} & $\begin{array}{l}\text { JSC “Ukrainian } \\
\text { Railways” }\end{array}$ & $\begin{array}{l}\text { Regular reporting; General } \\
\text { meetings, round tables, discussion } \\
\text { panels. }\end{array}$ & \multirow{5}{*}{ Win-Win } \\
\hline & Carriers & Joint projects; Working meetings. & \\
\hline & Business partners & $\begin{array}{l}\text { Joint projects; Meetings; } \\
\text { Transparent competitive } \\
\text { procedures; Contractual activity; } \\
\text { Talks. }\end{array}$ & \\
\hline & Cargo owners & $\begin{array}{l}\text { Complaints handling, focus } \\
\text { groups, surveys; Supervisory } \\
\text { boards, joint research and agreed } \\
\text { development strategy. }\end{array}$ & \\
\hline & Ukrainian government & $\begin{array}{l}\text { Active participation in the state } \\
\text { legislative bodies projects - } \\
\text { involvement in the development, } \\
\text { approval; Talks; Meetings. }\end{array}$ & \\
\hline $\begin{array}{l}\text { Group } 2 \text { "high } \\
\text { interest \& low } \\
\text { influence" }\end{array}$ & The industry employees & $\begin{array}{l}\text { General meetings; Surveys; } \\
\text { Career management system; } \\
\text { Social support; Motivation system; } \\
\text { Hotline. }\end{array}$ & Keep Informed \\
\hline \multirow{2}{*}{$\begin{array}{l}\text { Group } 1 \text { "low interest } \\
\text { \& low influence" }\end{array}$} & $\begin{array}{l}\text { Non-governmental } \\
\text { organization }\end{array}$ & $\begin{array}{l}\text { Surveys; Joint projects; Social } \\
\text { programs implementation; Related } \\
\text { projects participation; Talks. }\end{array}$ & \multirow{2}{*}{ Keep Support } \\
\hline & Mass media & $\begin{array}{l}\text { Public reporting; Information on } \\
\text { activities (website, social networks, } \\
\text { periodicals); Feedback. }\end{array}$ & \\
\hline
\end{tabular}

$10 \%$ - will increase; $10 \%$ - will not change; others - hard to say.

The key reforming stakeholders for the railway transportation market considered by respondents include: JSC “Ukrainian Railways", private carriers, cargo owners and the Ukrainian government. Respondents were asked to assess the interest degree and the impact of 10 stakeholders resulting in the stakeholders map. The developed map served as a basis for interaction strategies substantiation for 4 strategic stakeholder groups. For example, the stakeholders group "high interest \& high influence" affecting greatly the future of railway transport of Ukraine, interaction strategy "Win-Win" has been proposed, involving numerous methods of interaction usage. This strategic stakeholders group of interests can be divided into economic and political. However, in the JSC "Ukrainian Railways" structure, they are closely intertwined provoking conflict and acting as a stupor for the liberalization process. Political factors (the 1st place), according to respondents, are crucial (for comparison, economic factors, given the global crisis of COVID-19, take the 2nd place). For example, a new bill "On Railway Transport of Ukraine" adoption could create a "flywheel effect" on the way the railway market liberalizing but delaying the necessary bills adoption creates a "vicious circle effect" (typical situation today).

The liberalization process for the railway transportations market of Ukraine is characterized as large-scale and complex, which is why the issue of this study is a promising area for authors' future researches. 


\section{References:}

1. Ofitsiinyi veb-sait "Ukrzaliznytsia" [Ukrainian Railways. Official website]. Available at: https://www.uz.gov.ua/ (accessed 15 July 2020).

2. Stratehiji rozvytku AT "Ukrzaliznycja" na 2019-2023 roky [JSC "Ukrzaliznytsia" development strategies for 2019-2023]. Available at: https://zbk.org.ua/wp-content/uploads/2019/09/\%D0\%A1\%D1\% 82\%D1\% 80\%D0\%B0\%D1\%82\%D0\%B5\%D0\%B3\%D1\%96\%D1\%8F-Typography.pdf laccessed 15 July 2020).

3. Freeman, Harrison, Wicks, Parmar, and DeColle (2010). Stakeholder Theory: The State of the Art, Cambridge, U.K. : Cambridge University Press.

4. Bhattacharya, C. B., \& Korschun, D. (2008). Stakeholder Marketing: Beyond the Four Ps and the Customer. Journal of Public Policy \& Marketing, 27(1), 113-116. DOI: https://doi.org/10.1509/jppm.27.1.113

5. Krykavskyy Y., Stasiuk K. (2019) Railway freight transportation liberalization as a solution for improving client services quality // SHS Web of Conferences, vol. 67. DOI: https://doi.org/10.1051/shsconf/20196703007

6. Intehrovanyi zvit Ukrzaliznytsi 2018 (Shchorichnyi zvit) [Ukrzaliznytsia Integrated Report 2018 (Annual Report)]. Available at: https://pbcc.com.ua/download/uz-2018.pdf (accessed 15 July 2020). (in Ukrainian)

7. Ukrainian Institute for the Future (2018). Chy ye maibutnie v ukrainskoho zaliznychnoho transportu [ls there a future for Ukrainian railways]? Available at: https://www.uifuture.org/publications/ reports/24515-chy/ye/maybutnie/v/zaliznychnoho/transportu (accessed 15 July 2020). (in Ukrainian)

8. Ukrainian Logistics Alliance (2018). Ekspres analiz 2018, pro hotovnist ukrainskoi zaliznytsi do vprovadzhennia pryvatnoi tiahy, stan vantazhnykh vahoniv ta zakonoproekt \# 7316 [Express analysis 2018, on the readiness of the Ukrainian railways to introduce private traction, the freight cars condition and the bill № 7316]. Available at: https://logisticsmanagement.files.wordpress. com/2018/07/d0b6d0b4d0bfd183d0b1d0bbd0b8d0bad0b0d186d0b8d18f-2.pdf/ (accessed 15 July 2020). (in Ukrainian)

9. Dykan V., Solomnikov I. (2017). Inzhynirynho-marketynhovyi tsentr innovatsiinykh tekhnolohii yak osnova aktyvizatsii innovatsiino-investytsiinoho potentsialu pidpryiemstv zaliznychnoho transportu [Engineering and marketing center of innovative technologies as a basis for activating the innovation and investment railway transport enterprises potential]. Transport Economics and Industry Bulletin: scientific works compilation, no. 57, 9-20. (in Ukrainian)

10. Chornopyska N., Stasiuk K. (2019) Rail Freight Development Prospects in Ukraine. Multi-Authored monograph "Prognostication and planning of economic development: microeconomic and macroeconomic levels". Lithuania: Publishing House "Baltija Publishing", vol. 1, 227-240.

11. Verzuh, E. (2005). Stakeholder management strategies: applying risk management to people. Paper presented at PMI Global Congress 2005-North America, Toronto, Ontario, Canada. Newtown Square, PA : Project Management Institute.

12. Asotsiatsiia Ukrainskykh zaliznychnykh pereviznykiv [Official website "Association of Ukrainian Railway Carriers"]. Available at: http://locomotive.net.ua/members-of-the-association-2/ (accessed 29 July 2020).

\section{Список використаних джерел:}

1. Офіційний веб-сайт “Укрзалізниця". URL: https://www.uz.gov.ua/ (дата звернення: 15.07.2020).

2. Стратегія розвитку АT "Укрзалізниці" на 2019-2023 роки. URL: https://zbk.org.ua/wp-content/upl oads/2019/09/\%D0\%A1\%D1\%82\%D1\%80\%D0\%B0\%D1\%82\%D0\%B5\%D0\%B3\%D1\%96\%D1\% 8F-Typography.pdf (дата звернення: 15.07.2020).

3. Freeman, Harrison, Wicks, Parmar, and DeColle, Stakeholder Theory: The State of the Art, Cambridge, U.K. : Cambridge University Press, 2010.

4. Bhattacharya, C. B., \& Korschun, D. Stakeholder Marketing: Beyond the Four Ps and the Customer. Journal of Public Policy \& Marketing, 2008, 27(1), 113-116. DOI: https://doi.org/10.1509/jppm.27.1.113

5. Krykavskyy Y., Stasiuk K. Railway freight transportation liberalization as a solution for improving client services quality. SHS Web of Conferences. 2019. Vol. 67. DOI: https://doi.org/10.1051/ shsconf/20196703007

6. Інтегрований звіт Укрзалізниці 2018 (Щорічний звіт). URL: https://pbcc.com.ua/download/uz-2018.pdf (дата звернення: 15.07.2020).

7. Український інститут майбутнього: Чи є майбутнє в українського залізничного транспорту. URL: https://www.uifuture.org/publications/reports/24515-chy/ye/maybutnie/v/zaliznychnoho/ №transportu (дата звернення: 15.07.2020).

8. Український Логістичний Альянс: Експрес-аналіз 2018, про готовність української залізниці до впровадження приватної тяги, стан вантажних вагонів та законопроект № 7316. URL: https://logisticsmanagement.files.wordpress.com/2018/07/d0b6d0b4d0bfd183d0b1d0bbd0b8 d0bad0b0d186d0b8d18f-2.pdf/ (дата звернення: 15.07.2020). 
9. Дикань В., Соломніков І. Інжиніринго-маркетинговий центр інноваційних технологій як основа активізації інноваційно-інвестиційного потенціалу підприємств залізничного транспорту. Вісник економіки транспорту і промисловості : Зб. наук. праць. 2017. 57, 9-20.

10. Chornopyska N., Stasiuk K. Rail Freight Development Prospects in Ukraine. Multi-Authored monograph "Prognostication and planning of economic development: microeconomic and macroeconomic levels". Lithuania: Publishing House "Baltija Publishing". 2019. Vol. 1. 227-240.

11. Verzuh, E. Stakeholder management strategies: applying risk management to people. Paper presented at PMI Global Congress 2005-North America, Toronto, Ontario, Canada. Newtown Square, PA : Project Management Institute, 2005.

12. Асоціація Українських Залізничних перевізників. URL: http://locomotive.net.ua/members-of-theassociation-2/ (дата звернення: 29.07.2020). 